\title{
Surfaces
}

\section{SHAKESPEREAN APPARATUS: EXPLICIT TEXTUAL STRUCTURES AND THE IMPLICIT NAVIGATION OF ACCUMULATED KNOWLEDGE}

\author{
Raymond G. Siemens
}

Volume 8, 1999

HUMANITÉS ET INFORMATIQUE : QUI A LES COMMANDES?

HUMANITIES AND COMPUTING: WHO'S DRIVING?

URI : https://id.erudit.org/iderudit/1065078ar

DOI : https://doi.org/10.7202/1065078ar

Aller au sommaire du numéro

Éditeur(s)

Les Presses de l’Université de Montréal

ISSN

1188-2492 (imprimé)

1200-5320 (numérique)

Découvrir la revue

Citer cet article

Siemens, R. G. (1999). SHAKESPEREAN APPARATUS: EXPLICIT TEXTUAL

STRUCTURES AND THE IMPLICIT NAVIGATION OF ACCUMULATED

KNOWLEDGE. Surfaces, 8. https://doi.org/10.7202/1065078ar

\section{Résumé de l'article}

Dans son exploration du potentiel pour la navigation hypertextuelle mis en place par la nouvelle compréhension du terme « texte » dans les humanités, l'article analyse une activité traditionnelle propre à la recherche - la préparation de notes pour une édition critique (ici celles des sonnets de Shakespeare). Il propose d'étendre le type d'interaction que permettent les outils avancés d'analyse textuelle à l'ensemble du matériel qui peut être lié au texte. Qui plus est, les patrons sémantiques, surtout lorsqu'on les identifie avec des outils informatiques, opèrent de façon similaire au lien hypertextuel.
Copyright $\odot$ Raymond G. Siemens, 1999

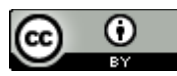

Ce document est protégé par la loi sur le droit d'auteur. L'utilisation des services d'Érudit (y compris la reproduction) est assujettie à sa politique d'utilisation que vous pouvez consulter en ligne.

https://apropos.erudit.org/fr/usagers/politique-dutilisation/ 


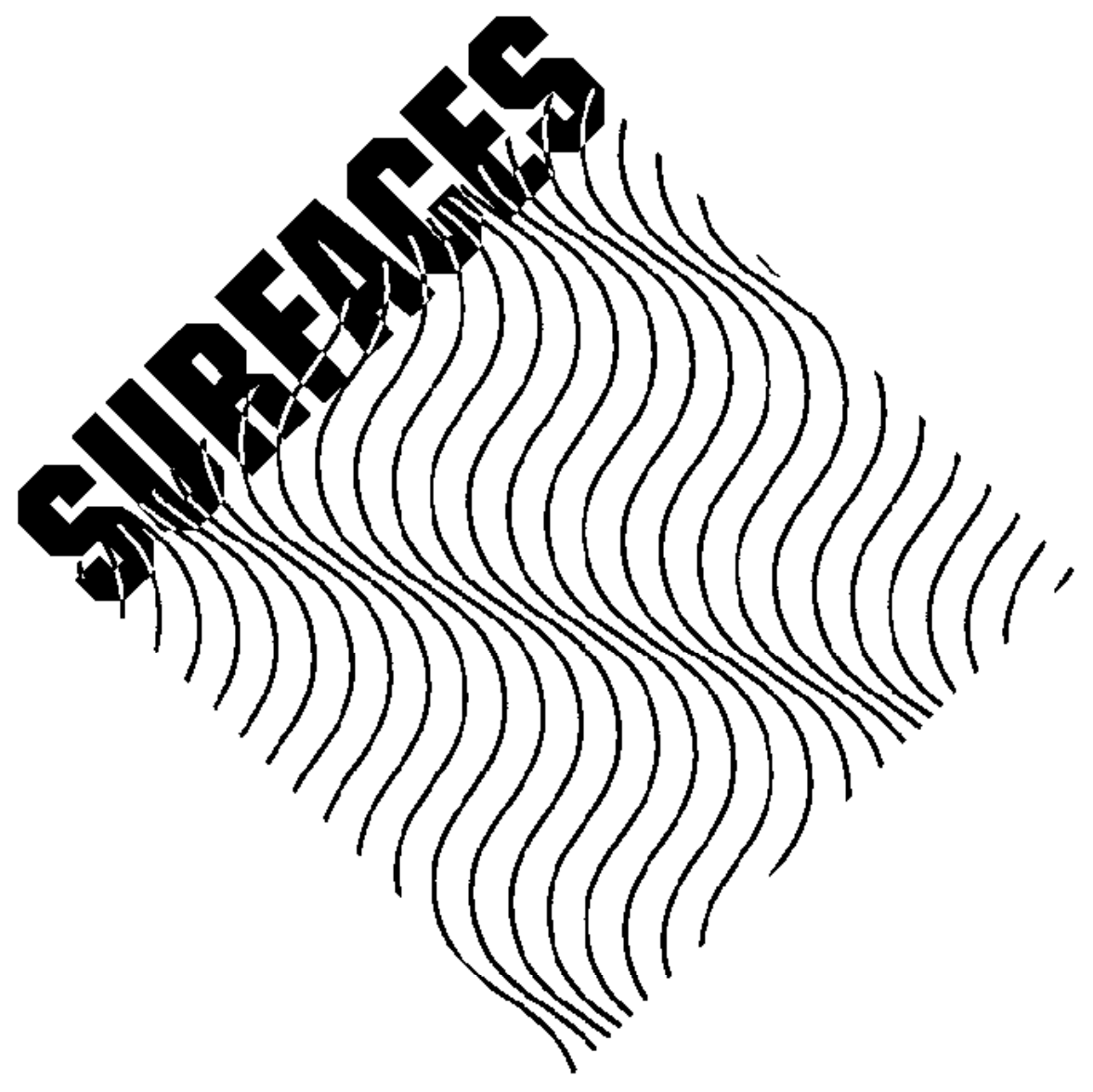

SHAKESPEREAN APPARATUS

EXPLICIT TEXTUAL STRUCTURES AND THE IMPLICIT NAVIGATION OF ACCUMULATED KNOWLEDGE

$\underline{\text { Raymond G. Siemens }}$ 


\section{Rédacteur en chef:}

Jean-Claude Guédon

\section{Comité fondateur:}

Wlad Godzich

Walter Moser

Michel Pierssens
Christie McDonald

Antonio Gómez-Moriana

Gilles Bibeau

\section{Remerciements:}

SURFACES peut paraître grâce à un soutien des Presses de l'Université de Montréal, ainsi qu'à une aide matérielle importante (locaux, mobilier, services informatiques) de l'Université de Montréal.

\section{Adresses:}

\section{SURFACES}

Département de littérature comparée Université de Montréal C.P. 6128, succ. Centre-ville Montréal, Qc, Canada H3C 3J7

Tél.: (514) 3435683

Fax: (514) 3435684

Accès sur INTERNET www.pum.umontreal.ca/revues/surfaces

Assistance technique et questions éditoriales: guedon@ere.umontreal.ca ISSN: 1188-2492 


\section{Soumission des textes}

Vous pouvez soumettre vos articles, revues, notes, commentaires ou autres aux éditeurs par courrier électronique, par disquette ou par lettre. En ce qui concerne les notes bibliographiques, veuillez suivre le protocole du MLA. Nous vous demandons également de joindre à votre texte un court résumé de 3 à 4 lignes.

Tout article publié que l'auteur voudra modifier ultérieurement sera de nouveau évalué. Si accepté, il se substituera à la première version avec une nouvelle date et la mention v. 2.

Tout texte reste la propriété de son auteur. Néanmoins, SURFACES demande d'être citée à l'occasion de toute autre publication du texte en question.

\section{Citation des textes}

Pour toute citation, veuillez consulter le document source afin d'obtenir la dernière version du texte qui vous intéresse et vous baser sur la pagination flottante (/pp. $\mathrm{xx} /$ ) plutôt que sur la foliation (pied de page). Si vous n'avez pas accès au courrier électronique, adressez-vous aux éditeurs qui pourront vous vendre une copie papier ou sur disquette. 


\title{
RÉSUMÉ
}

Dans son exploration du potentiel pour la navigation hypertextuelle mis en place par la nouvelle compréhension du terme «texte» dans les humanités, l'article analyse une activité traditionnelle propre à la recherche - la préparation de notes pour une édition critique (ici celles des sonnets de Shakespeare). Il propose d'étendre le type d'interaction que permettent les outils avancés d'analyse textuelle à l'ensemble du matériel qui peut être lié au texte. Qui plus est, les patrons sémantiques, surtout lorsqu'on les identifie avec des outils informatiques, opèrent de façon similaire au lien hypertextuel.

\begin{abstract}
In its exploration of the potential for hypertextual navigation offered by the new humanistic understanding of text, the article analyzes a traditional humanistic activity - that of annotating a scholarly edition (in this case, one of Shakespeare's sonnets). It asserts that the interaction allowed by advanced textual analysis software are transferable to all the material that can be linked to the text. Moreover, semantic patterns, especially those identified with machine facilitation, operate in ways akin to hypertextual links.
\end{abstract}


Associating the concerns of the humanist with issues of technology, Northrop Frye commented over a decade ago that

... three of the most seminal mechanical inventions ever devised, the alphabet, the printing press, and the book, have been in humanist hands for centuries. The prestige of humanists in the past came largely from the fact that they lived in a far more efficient technological world than most of their contemporaries. (7-8)

The technologies to which Frye draws attention - the alphabet, the printing press, and the book - are, notably, associated foremostly with textual culture; his comments, which were presented as a keynote address at the 1989 joint international conference of the Association for Computers and the Humanities and the Association for Literary \& Linguistic Computing, would contextualize that conference's consideration of comparativelyrecent computing technology with relation to its more established predecessors. While acknowledging that text and the machinery involved in its creation, manipulation, and dissemination have had a firm place at the centre of the humanistic identity, one of the main points of Frye's address is found in an argument that is directly associated with what is often acknowledged to be the source for the idea of hypertext: this is Vannevar Bush's "As We May Think," in its expression of the idea of "building a trail of many items" through textual materials. Bush's discussion of the problems - specifically that of management - associated with the gross accumulation of scientific knowledge is re-articulated by Frye in a discussion of the Wissenschaft period of humanistic knowledge accumulation; of this period, Frye comments:

/pp. 5-6/ 
... its great scholars amassed an awesome amount of information. Its imaginative model was the assembly line, to which each scholar "contributed" something, except that the aim was not to produce a finite object like a motor car, but an indefinitely expanding body of knowledge. (4)

The problems associated with Wissenschaft-era accumulation have been more recently elaborated in the terms of the new humanist by Bill Winder, who concludes that our own period, the neo-Wissenschaft era, "brings with it . . . issues of retrieval and reuse," noting that the challenge for us is to be "as efficient at retrieving the information we produce as we are at stockpiling it"; we are to do so with the assistance of the computer, the "humanist's machine."

My intention in tracing such a development - Frye's thoughts on the technologies of humanism and on Wissenschaftera accumulation, Bush's earlier comments on much the same as well as the idea of hypertext, and Winder's argument about the new humanist's role and our own neo-Wissenschaft era - is to suggest an appropriate context for the concerns of this paper, a paper in which I tread a path others have walked before. The frame of reference for my paper ${ }^{2}$ is text, and the textual edition,

1 Winder $(164,165)$.

2 I wish to thank the Killam Trust, and the University of Alberta, for its generous support during the time in which this article was written. A version of this paper was presented on the MLA Committee for Scholarly Edition's "Creation and Use of Electronic Editions" panel at the meeting of the Modern Language Association, San Francisco (28 December 1998), and this paper also draws upon some material from earlier conference presentations: "Annotating Shakespeare," "A worlde of wordes," "Disparate Structures,"and "The art of mightie words." 
/pp. 6-7/ with a promise in my title of discussing the navigation of textual structures and, presumably, hypertext. Within this frame of reference, it is especially important to note the appropriateness of the specifically-humanistic context into which Frye and Winder transpose the challenge presented by the more scientificallyoriented Bush. This is so not only because of the way in which hypertextual theory has, in recent years, seen assimilation into a common humanistic understanding of what it is one means by text ${ }^{3}$ this is so, also, because of the way in which a new humanistic understanding of text - and the textual edition ${ }^{4}$ contributes, firstly, to a notion of hypertext that has evolved significantly since its early articulation by Bush and, secondly, to the problem of information management and navigation that was articulated some fifty years ago by Bush, and has been rearticulated since by Frye and Winder, among others, with regard to literary materials. Lastly, my title's reference to "Shakespearean apparatus" is intended to narrow that focus slightly, gesturing toward the process of scholarly annotation - a process which has, for a generation of humanists interested in electronic textuality, become a touchstone for hypertext's incorporation into the electronic scholarly edition — and, specifically, gesturing to annotation as it might apply to the examples on which I rely in this paper drawn from the work of Shakespeare.

3 Oft-cited in reference to this are Delany and Landow (Hypertext, and The Digital Word), Landow (Hypertext, and Hyper / Text / Theory), Ted Nelson, and Keep et al. (as a primer on hypertext), among others.

4 In the context of some humanities computing techniques, Fortier notes that it is text that is at the heart of concerns in literary studies. On hypertext and scholarly editions, see Landow ("Hypertext," and "Footnotes"), Faulhaber, McGann, Lavagnino, Siemens ("Disparate Structures"), and the articles in Finneran, among others. 


\section{What We Already Do: Presenting and Annotating the Text of Shakespeare's Sonnet 138}

Perhaps the best way to begin is with a practical example, one taken from Shakespeare's Sonnets, and one with which many may already be familiar: "When my love swears that she is made of truth" (\#138).

A good print edition's rendering of Sonnet 138, taken from G.B. Evans' recent edition (101), is given in Figure 1.1. /pp.8-9/

\section{Figure 1.1}

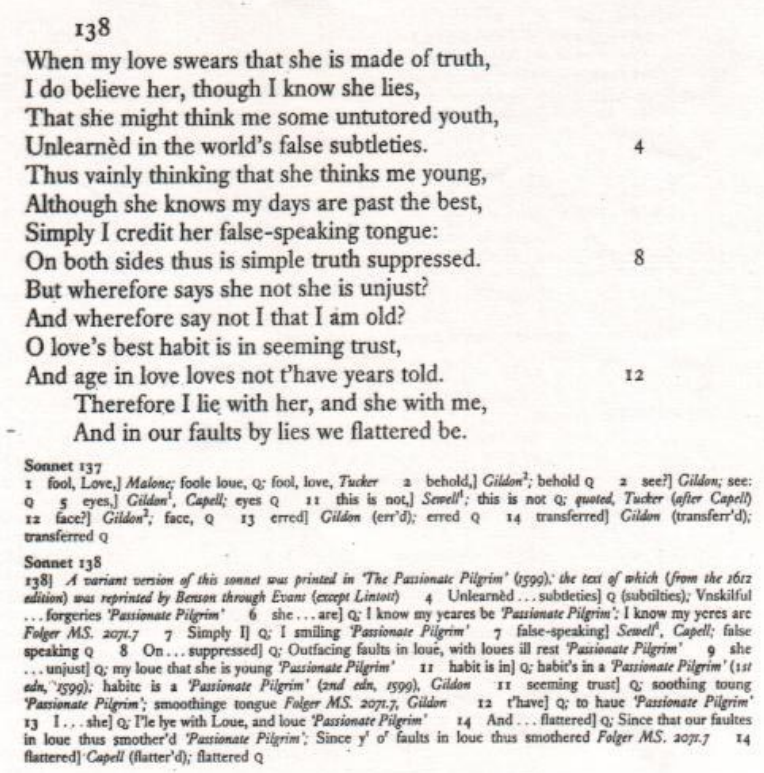


There is much that is familiar - and, to my mind, much that is reassuring - about such a presentation. We understand, in looking at an example such as this, that the text has been modernised and regularised. We also understand the ways that the various parts of the text - the sonnet and its textual apparatus and annotations - interrelate with one another.

For one used to working with such an edition regularly, the reading eye moves seemingly in a natural manner (should one wish it to) between the lines of verse and the lines of textual commentary. Seeing that there are no accidental variants, one presumes that only substantive variants are being treated; using the information given, related versions of the sonnet can be reconstructed. And, noting that there is nothing by way of gloss and interpretive notes, the trained reader may also, without thinking much about it, use a finger or bookmark for easy passage to the commentary's assumed place later in the book (256-7; see Figure 1.2). A note in that commentary, I should add, discusses the mutual association of sonnets 138 and 144 through their printing in The Passionate Pilgrim (1599) and directs us to it. It also directs us to other texts,primary and secondary materials, that can inform our reading of the sonnet. Fingers or bookmarks may hold places in the book, but the eye and mind move about, working from place to place - text, textual apparatus, and commentary - associating each with each, but always with the text of the sonnet as the main point of interest; other materials are encountered in relation to it, and those that are encountered are present because of their ability to illuminate the sonnet. 5

/pp. 9-10/

5 Should one wish another style of presentation, or the presentation of different text-related materials, one would use another style of edition: say, variorum (with a more conservative presentation and, likely, a wider textual collation, with a history of pertinent criticism; see Rollins' edition [1.353-5]; later, this is seen in Figures 3.1, 3.2, and 3.3) or diplomatic/documentary (transcription or 


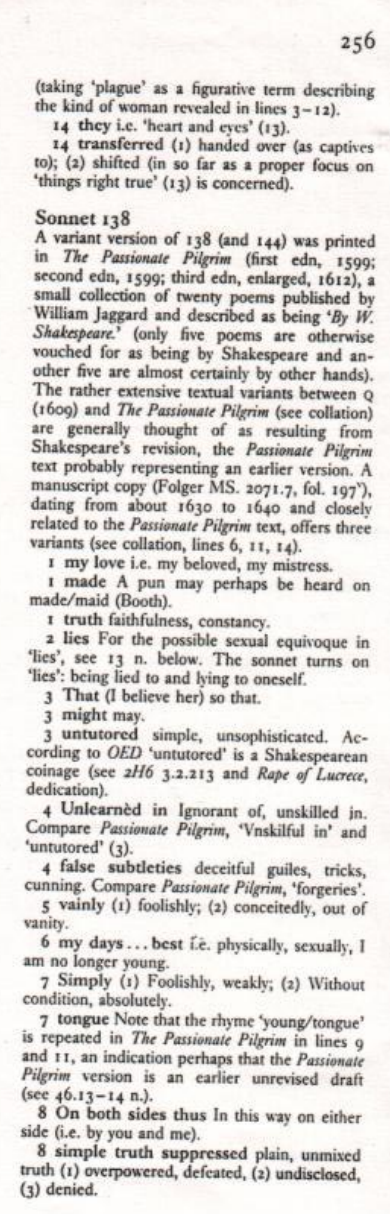

Figure 1.2
257

9 But wherefore ... unjust But why does she not admit that she is (I) 'thonest' = chaste.). 'uniust' looks back to lines $\mathrm{t}-2$; in Passiona: Pilgrim, line 9 introduces a different twist - that the woman concerned is herself 'not young' (see collation).

II love's best ... trust love's most effective (I) attire, guise, (2) settled practice, policy lies in giving the appearance of faith or constanc $=$ seemly). The effectiveness of this 'policy' in love is illustrated by lines $\mathrm{I}-2$. The Passionale Pilgrim substitutes 'in a soothing toung' for Q' 'in seeming trust', a reading that even more obviously looks back to lines $\mathrm{I}-2$.

12 age in love i.e. older persons who fall in, or are infatuated by, love (ilike the poet who generalised, have, respectively, immediate reference to the woman involved and the poet.

12 thave years Almost all editors substituse Passionate Pilgrim's 'to have' for Q's 'thave'; Q's reading, however, throws emphasis on 'years' (taken as disylabic) where, I belongs.

12 told (1) counted; (2) recounted, reported. 13 I lie...me (1) 1 lie to her and she lies to each other. Dekker devotes some eight pages in The Seron deadly Sinnes of London (1606), '2. Lying', to ringing the same changes on lie? 14 in our faults through our (1) defects, failings, (2) offences.

14 lattered be are (1) deceived, beguiled, (2) gratied, pleased 's reading of the line (see collation), by substituting 'smother'd' for 'lattered, limits the meaning to (1). Compare Ovid, Amore II, xi, 53-4 (as translated by Marlowe): "lle thinke all true, though it be feigned matter. flatter:

Sonnet 139
Sonnet 139 reflects a sonnet convention: the lover pretends to find a justification or excuse (see lines 9-12) for his mistress's unkindness. If Stella (1591), 48.

1 call not me i.e. do not ask me. 1. justiry (3) approse of Suggested perhaps and 'shoper, is uniust' (138.9); neither word occurs eisewhere in the Sonnets.

I wrong The 'wrong' and 'unkindness' (2) refer not to the conventional 'coldness' of poet's mistress in loving 'elsewhere' ( 5 ) and in,

facsimile, or both, with notes and commentary off the page; see Booth's edition [118-9, 476-81]). 
Such ideas about visually 'navigating' an edition are commonplace, and my conclusion regarding those ideas is equally so. Because we are familiar with the type of display (text, apparatus, and commentary) used by Evans, we already understand the ways in which such editions associate related texts and textual materials; moreover, we understand these ways to the extent that they are seemingly intuitive.

\section{Formalising Associations in the Electronic Medium}

It is that intuition on which most of us draw when we approach the scholarly edition in the electronic medium - an artifact that is increasingly being referred to as the hypertextual edition or the electronic edition. Before turning to a discussion of the electronic edition, though, let us consider one further aspect of the print edition. In the print edition, the idea of the "trail of many items" upon which Bush pontificated is implicit, it is understood to exist, and rarely needs explicit articulation. While we regard such association of one thing and the next as something that can be navigated intuitively on the page or across several pages, and while in our familiarity we regard the structures through which we navigate to be implicit, a trail is clearly and explicitly there. That trail is established by the editor, based on materials left us by the author and others, and is presented to us in a familiar, accepted manner.

What we typically do now when we bring such a text into the electronic medium - that is, when we do it as professionals with attention to scholarly standards - is to formalise, to make explicit, the seemingly-intuitive relation of one thing and the next; we build, hypertextually, that trail of many items of which Bush spoke. This is a relatively straightforward procedure, wherein (over one or more electronic documents) materials associated /pp. 
11-12/ with the central text are presented, and the individuallyassociated bits of information are hypertextually linked. As many of us are familiar, passages for which there are variant readings or annotations are, in a hypertextual edition, marked in such a way that the reader knows that selecting that textual passage (with a mouse, pointing and clicking) will lead to a display of variant readings or annotations; such passages would be associated, again typically, by lines of code in the electronic text that set out exactly that, if a certain piece of marked data is selected, another piece of specifically-demarcated data will be displayed. By way of example, in our text of Sonnet 138 the following relationship of materials that are presented in the print edition would be formalised by hypertextual links:

Text (1. 14): And in our faults by lies we flattered be.

Marked text (as per Evans' edition): And in our faults by lies we flattered

Linked to (textual apparatus):

Q; Since that our faultes in loue thus smother'd 'Passionate Pilgrim'; Since $\mathrm{y}^{\mathrm{t}} \mathrm{o}^{\mathrm{r}}$ faults in loue thus smothered Folger MS. 2071.7

The relation of the text to materials in the commentary operate in a similar fashion, as follows:

Text (1. 14): And in our faults by lies we flattered be.

Marked text (as per Evans' edition): flattered be

Linked to (commentary [Evans' ed. 256-7]): 
are (1) deceived, beguiled, (2) gratified,

/pp. 12-13/

pleased (even though improperly). The Passionate Pilgrim's reading of the line (see collation), by substituting 'smother'd' for 'flattered', limits the meaning to (1). Compare Ovid, Amores II, xi, 53-4 (as translated by Marlowe): 'Ile thinke all true, though it be feigned matter. / Mine owne desires why should my selfe not flatter?'

Selecting a passage of marked text leads us from that text to its linked apparatus and/or commentary, much as our mind, eye, and fingers might work together in unison with the print edition itself.

\section{Considering 'Inclusivity' — Print and Electronic}

When we bring such a text to the electronic medium, we typically do something else as well: we participate - or at least desire to participate - in a trend towards greater inclusivity. Directly associated with the flexibility and economics of storage in that medium as compared to print, when we bring a text to the computer we tend to wish to provide more than is provided in print editions, we tend naturally to move towards being more fully comprehensive - linking with a collection of textual and critical materials, providing fuller commentary, and so forth. This tendency ensures that an electronic edition, again typically, will contain a number of linked associations covering material beyond what one might expect in a print edition. Thinking of Shakespeare's Sonnet 138, we may consider that version provided by The Arden Shakespeare CD-ROM which, for all its texts, provides extensive textual witnesses in digital /pp. 13-14/ 


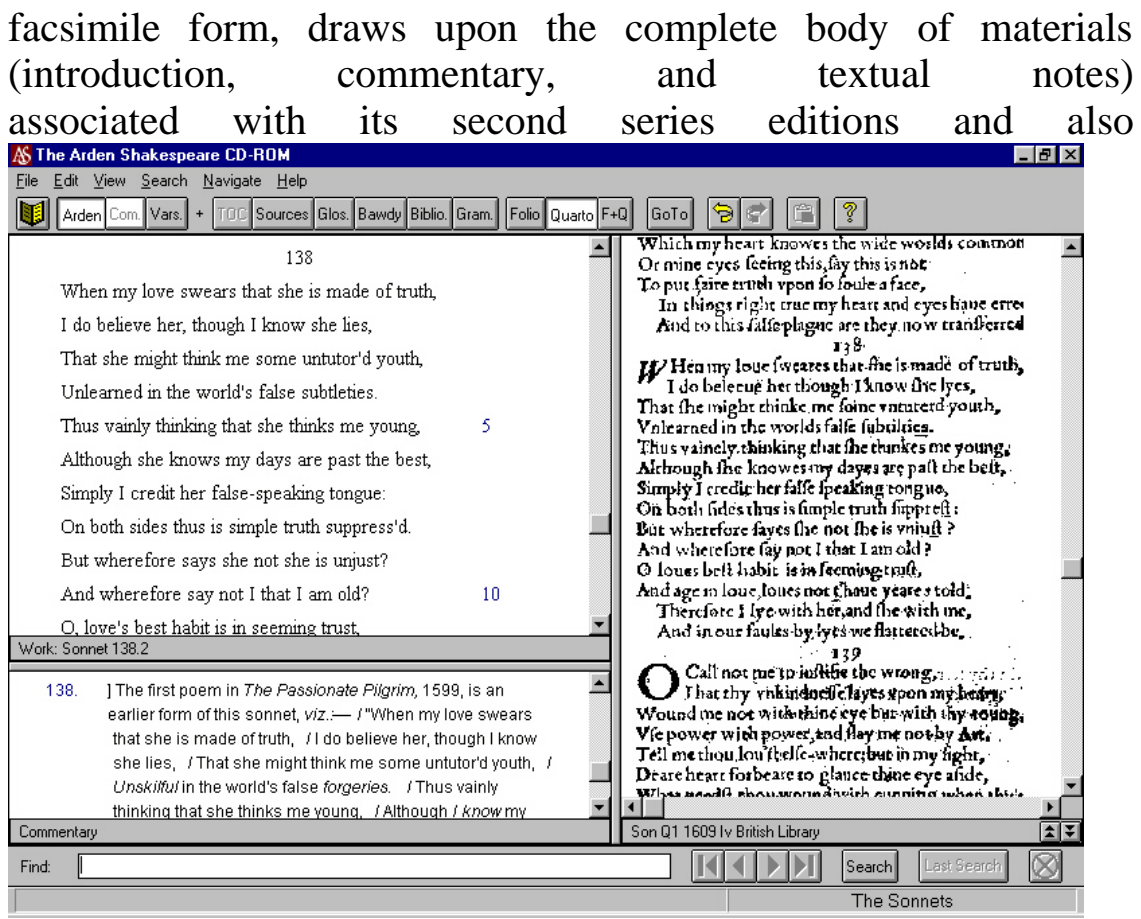

Figure 2

includes a number of scholarly works helpful to the student and reader of Shakespeare. ${ }^{6}$ (Of several 'views' of the text and testrelated materials that are possible via this edition's delivery software, one view is seen in Figure 2.)

/pp. 14-15/

6 Among these scholarly works are Bullough's Narrative and Dramatic Sources of Shakespeare, Bevington's Shakespeare bibliography, Abbott's A Shakespearean Grammar, Onions and Eagleson's A Shakespeare Glossary, and Partridge's Shakespeare's Bawdy. A further discussion of this edition can be found in my "Review of the Arden Shakespeare CD-ROM: Texts and Sources for Shakespeare Studies," in Early Modern Literary Studies, at <URL: http://purl.oclc.org/emls/04-2/rev_siem.html>. 
Given this trend toward further inclusivity, those faced with the pragmatics of such editing might ask this question: where does such inclusivity of materials related to the edition end? One answer to this is that inclusivity ends with a choice made by the individual editor, who could only be expected to have so much breadth and depth of knowledge, time, and patience, for a project. Expressed in a recent paper, such a conclusion was reached after one editor's desire to include everything was quelled by the realisation of what including everything meant in terms of editorial labours - with reference also to the act of relating everything properly to everything else. ${ }^{7}$

While I think we all have sympathies with this view, another answer must also be considered. As mentioned earlier, Bush articulated a model of scholarly production and an idea regarding the navigation of the increasingly-unnavigable body of knowledge that was being produced; as well, Frye articulated (as has Winder) the need for humanists to turn their attention to navigating that body of knowledge as it relates to their own discipline. For each, their notion of inclusivity was something that was total - a notion in keeping with the frame of reference for materials in the electronic medium provided by early hypertext guru Ted Nelson. The hypertextual world envisioned by Nelson involves an inclusivity that ends only with all the related matter to be found in the medium; ${ }^{8}$ here, each individual work is /pp.15-16/

7 See Graver, whose argument was presented and well received, before publication, at the 1997 Modern Language Association conference.

8 This may well be, as John Lavagnino has suggested to me privately, a transference to the electronic medium of the desire for 'total libraries' that evolved from library cataloguing movements in the late print era. More specific to my example of Shakespeare's work is the range of materials that Louis Marder would, ideally, have appear in a definitive edition; he notes: 
a small part of a much larger whole, a whole united by topic and clearly connected by hypertextual associations that link related materials. As one of the most prominent literary hypertextual theorists of the past two decades has noted, the "Nelsonian vision . . . ultimately requires all texts to be linked together in a universal web or docuverse."9 While all materials extant in electronic form will not, of course, be generated by a single individual, the work of the individual will take its place as part of a much larger whole, a whole made up of individual components that have points of relationship (sometimes called "nodes") and that can be navigated with reference to those points.

For scholarly editions in the print medium, the challenge of inclusivity has resulted in the gathering and presenting, in a useful and condensed form, as much material as relates reasonably to a text, given a specific context. The best example of inclusivity in the print medium is the variorum model, with its extensive survey of text, scholarship and criticism. Our understanding of the scope that such editions are felt to hold is well-expressed by Hyder E. Rollins, editor of the 1944, two-volume /pp. 16-17/

Eventually, when everything necessary for further study will have been stored in a constantly updated Shakespeare data bank . . . and all the relevant information on every given act, scene, place, word, or line is retrievable on command, we may have the means for a universal, up-todate, constantly improving, eclectic "edition" of Shakespeare. (29)

On how this might be accomplished, he continues:

My solution is to call for a moratorium in the making of editions, and the writing of articles, too, for that matter, . . . and the channeling of efforts . . . to devise a project (for which I already have a preliminary plan) to computerize all that is known about Shakespeare's life, times, and work .... (29)

9 Landow ("Hypertext Editions"). 
variorum edition of Shakespeare's Sonnets; he notes, in his preface to that edition, that "To read all, or nearly all, the 'literature' under which Shakespeare's sonnets are submerged is a wearisome task that, at least up to the date 1942, should not have to be repeated" (v). This task should not have to be repeated because the variorum edition provides the apparatus necessary for the navigation of those materials up to the date of the edition's preparation. In examining Rollins' edition, one notes that - above and beyond presenting a text, a collation, and commentary along the lines of what Evans offers - Rollins provides a critical/scholarly survey for each sonnet, and a commentary geared towards the expression of earlier engagements of the piece (see Figures 3.1, 3.2 and 3.3.)

Like with the model provided by Evans, the way in which one navigates a variorum edition can be similarly duplicated in electronic hypertextual structures, the difference between the variorum and Evans' edition chiefly being the organisation that each brings to the types of material each presents. The variorum, by cataloguing and building on previous scholarship in an overt way as it does, brings an organisation to that material that allows one to navigate the related scholarship in addition to the text and its immediate commentary. The editorial labours involved - the "wearisome task" that Rollins referred to - are not light.

Nor are such labours light when we attempt to make explicit, in an electronic edition, the sorts of organisational patterns we find in the print variorum model. Moreover, when we accept inclusivity as it is defined in the electronic medium, it becomes apparent that in addition to the concerns associated simply with getting the material into the proper form, there is the further concern of relating that complex body of material to other pertinent materials available in electronic form. The materials - given the scope of inclusivity native to the electronic medium - /pp. 17-18/ 
Hen my loue fweares that the is made of truth,

I do beleeue her though I know the lyes, That fhe might thinke me fome vntuterd youth, Vnlearned in the worlds falie fubtilties.

Thus vainely thinking that fhe thinkes me young,

Although the knowes my dayes are paft the belt,

Simply I credit her falie fpeaking tongue,

On both fides thus is fimple truth fuppref:

But wherefore fayes the not fhe is vniuft?

And wherefore fay not I that I am old?

$O$ loues beft habit is in feeming truft,

And age in loue, loues not t'haue yeares told.

Therefore I lye with her, and the with me,

And in our faults by lyes we flattered be.

Printed from the $16 \mathrm{r} 2$ P. P. version by Ben., Gild.-Evans,

4. Vnlearned...sublilties] Vrskilfu

-nforgeries P. P., Ben., Gild.-Evans.

6. she knowes my dayes are] I know my yeares be P. P., Ben., Gild.Evans.

7. Simply $I] \cdot I$ smiling $P . P$.

Ben., Gild.-Evans.

false speaking] Hyphened by

Sew. ${ }^{1}, \mathrm{Mal}$. + .

lowes ill rest $P, P$. Ben Gild Evans

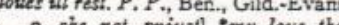

she is young P. P., Ben., Gild.-Evans.

A version of 138 appeared as sonnet $\mathrm{I}$ in the $P, P$., the first edition of which apparently belongs to the year ${ }^{159 g}$. The unique, fragmentary copy of that edition was issued in a collotype facsimile by ADNus late in 1939 . All the sonnet commentators and editors up to 1940 have been familiar only with the second $\left(r_{599}\right)$ and third $(16 \mathrm{r} 2)$ editions of the $P$. P. In the first edition the sonnet runs thus:

When my Loue sweares that she is made of truth, I do beleeue her (though 1 know she lies)

That she might thinke me some vntutor'd youth,

Vnskilful in the worids faise forgeries.

Thus vainiy thinking that she thinkes me young.

Although 1 know my yeares be past the best:

\section{Figure 3.1}

S U R F A C E S Vol. VIII.106

folio 18 


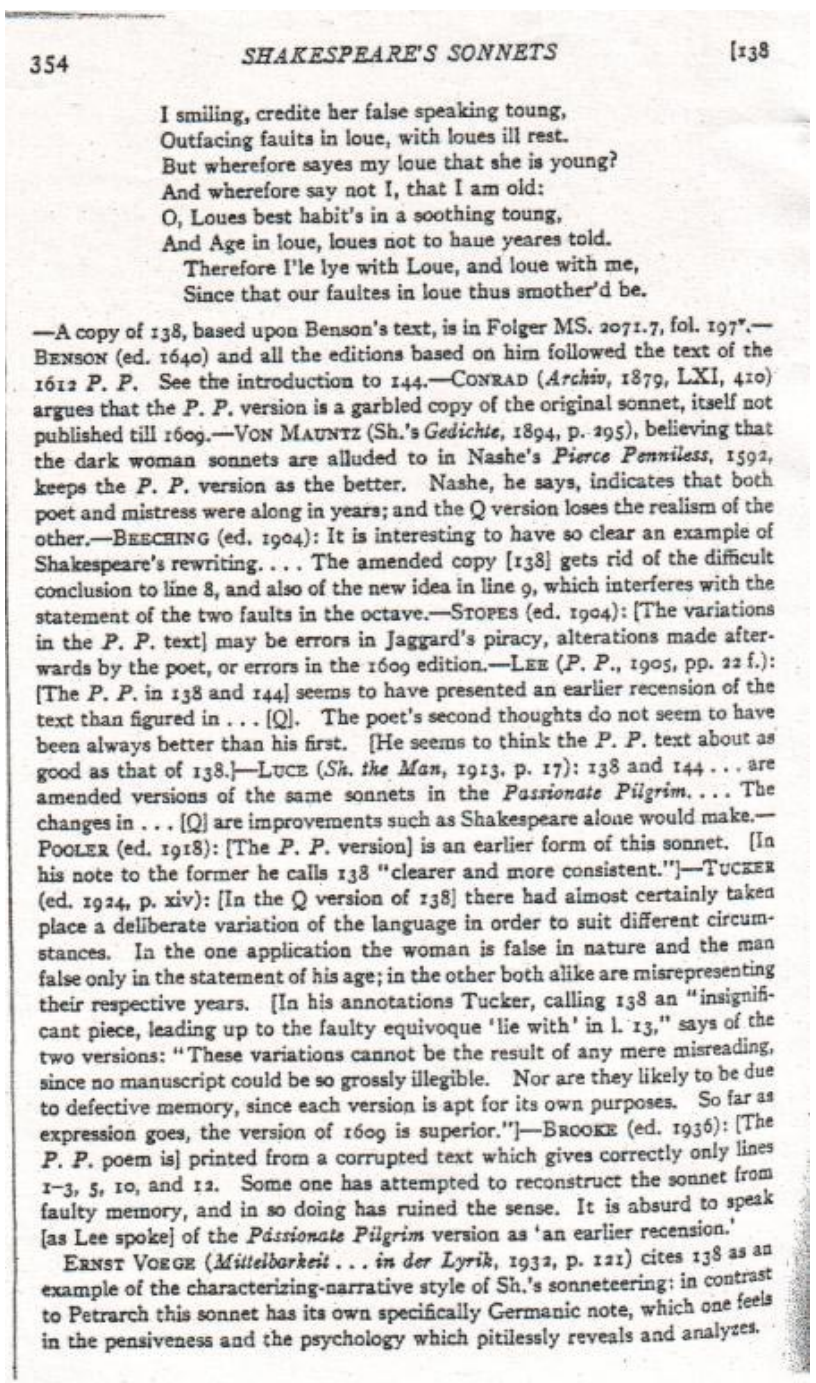

Figure 3.2 
I. truth] See $54.2 \mathrm{n}$.

2.] Traversi ( $A$ pproach to Sh., r938, pp. 44 f.): A line like ... [this] calls for an exactitude of thinking and feeling that a modern reader does not readily associate with emotional intensity. It is a type of poetry which justifies ambiguity, because its subtlety is balanced by its content, because it is able to gather the divergent possibilities of a single situation into the unifying framework of a realized convention.

3.] I. e. in order that, or so that, she might (or may) think, etc. "His credulity," says TUCKER (ed, 1924), "would be some evidence of his 'youth.'"

6.] DOWDEM $\left(P . P_{\text {., }} 188_{3}, \mathrm{p}\right.$. vii): I am inclined to believe that the earlier $[P . P$.$] and later [Q]$ readings are both those of the author of the sonnet.... Neither version is an entire success,... The logic of the sonnet requires something of both versions- "Although $I$ know she knows my years are past the best." - TUCKrg (ed. 1924): At the date of the first publication (1599) Shakespeare was 35. [Many other persons have commented on this fact, some with astonishment; but even today thirty-five is still regarded as "past the best " for love. See also 22.r n.]

7. Simply] SCrmidT (1875): Unconditionally, absolutely,-Pooler (ed. 1918): In my (assumed) simplicity.-NensoN and Hrt (ed. 1942): Foolishly.

8, 9.] Porter (ed, 1912, p. 274): The humorousness of the 1609 lines [when compared to those of the P. P.] in blaming her for a lack of truth in which the Poet shares, certifies to their superior accuracy.

8-14.] Dowden (P. P., $188_{3}$, p. vii): "My love" ... [in the P. P.] not only asserts her truth when she is really false, but also asserts her youth (her youth being past); evidently the balance of the cornposition (as well as the courtesy of a sonneteer) requires that there should be one lie on each side, and that the lady's lie should be an assertion of fidelity, the man's lie an implied assertion of his youth. And so it was worked out in .... [Q].

9. vaiust] Scrurdot ( 2875$)$ : Used of faithlessness in love.

ri.] Scirrdot (1874) defines habit: Appearance, deportment.-Tucker (ed. 1924): Love looks best (wears its best dress, or makes itself most attractive) where there is all the semblance (or pretence) of truth, - In the $Q$ change to seeming trust from the soothing toung of the P. P., says WoLrGanc Scmado (Angisa, 1938, LXII, 299), is expressed the torture of the poet, who must act contrary to truth and reason.

12. told] [. e. counted. See $30.10 \mathrm{n}$. and ontold at ${ }_{3} 6.9$.

14.] TUCKRR (ed. 1924): In regard to our respective defects we are flattered by reciprocal pretence of belief.

Figure 3.3 
will likely seem too many, and the process impossibly time consuming.

Recognising pragmatic limitations - of editorial labour, budgets, the deployment of symbolic capital in academe - and also recognising the valuable and important nature of the information provided in print editions, variorum and otherwise, we might best consider directing our editorial efforts to the electronic re-production (the recycling) of print-based editions in the electronic medium with a conception of inclusivity and association-of-textual-materials drawn from the variorum of the print medium. In effect, this would involve formalising with hypertextual links the associations that, in print, we understand intuitively and, thus, making more explicit and more immediately navigable the paths over which past editors have pored. As well, we might consider the duplication of this model in new, non-printbased variorum-like electronic editions; such a path has been recommended before, and with good justification. ${ }^{10}$

To proceed in this manner, however, is to accept something less than the medium promises to allow. As excellent contributions to scholarship as variorum editions are, they are objects that attempt to represent or fix, at a single moment in time, the work of an unfixed, ever-evolving - and thus dynamic scholarly community engaged in, as Frye notes, the process of stockpiling scholarship. Electronic editions that live up to the potential of the medium, especially in terms of the inclusivity that it allows, must also be dynamic; they must be able to navigate the contents of the edition in familiar ways, and also able to reflect and draw upon the growing, evolving, and /pp. 21-22/

10 A related suggestion is found in Landow ("Hypertext Editions"). 
unfixed stockpile of scholarship that relates to the matter of the edition. ${ }^{11}$

\section{Explicit Structures and Implicit Relations in all Text}

Elsewhere, I have discussed two dominant perspectives on the electronic scholarly edition: one, called the dynamic text, consists of an electronic text and advanced textual analysis software and presents, in essence, a text that "indexe[s] and concord[s] itself, allowing the reader to interact with it in a dynamic fashion"; 12 the other, called the hypertextual edition, "exploits the ability of hypertextual organisation to facilitate a reader's interaction with the apparatus (textual, critical, and otherwise) that traditionally accompanies scholarly editions, and with relevant external textual and graphical resources, critical materials, and so forth." 13 I have also urged that the two perspectives on the electronic scholarly edition should be united in practice - as they are, seemingly, in theory - so that the reader of such an edition could take advantage of both dynamic interaction with the text and its related materials, and also reap the benefits of the fixed hypertextual links that typify the standard relation of materials we find in a scholarly edition.

11 As well, literature on the subject suggests also that they must reflect the "archive" model of the electronic scholarly edition that Jerome McGann has recently championed (see also Ross), and the "operative paradigm for the hypertext document," which is the "electronic library" - in which "the reader encounters multiple points of authority, unexpected juxtapositions, and frequent occasions for making choices" (Landow "Footnotes").

12 See my "Disparate Structures" (9); such a text of the Sonnets is provided by Ian Lancashire and Hardy Cook, eds., Shake-speares Sonnets.

13 Faulhaber ("Textual Criticism" 134 ff.). 
/pp. 22-23/

In this paper, I wish to suggest the possibility that the level of interaction one can enjoy with an electronic edition itself, if facilitated in the style of the dynamic text, can replace much of the interaction that one typically has with a text's accompanying materials via explicit hypertextual links in a hypertextual edition. That is, I wish to assert that the principles of interaction allowed by a dynamic text are transferrable to the realm of textual apparatus and commentary, and well beyond into all materials in the medium that relate to the matter of the edition at hand. The ideas associated with a text that indexes and concords itself are portable to the idea of an edition (perhaps best called a dynamic edition) that has the ability, in effect, to annotate itself and provide its own apparatus, an electronic edition that employs sophisticated software to automate the process of formalising the associations we take for granted in editions akin to Evans' presentation of Sonnet 138 and that assists in the navigation of scholarship in ways akin to Rollins' variorum presentation of the same sonnet.

Such an edition embraces an electronic context and notion of inclusivity that Bush, Frye, Winder and Nelson have articulated; such an edition also requires that a significant amount of related scholarly material is available in electronic form. While much of this material is not yet available, what has been called the "interoperable digital library" - part of the emerging Global Information Infrastructure - is envisioned to provide much of this, and work on it progresses, albeit slowly. ${ }^{14}$ A number of critics have argued that World Wide Web is, essentially, already this, ${ }^{15}$ though it will be some time yet before materials /pp. 23-24/

14 See E. Fox, and his extensive references; also Delany (Universities).

15 See, for example, Landow ("Footnotes"). 
available on the World Wide Web will reach a state of development such that they will have as prominent a place in scholarship as that accorded a research library; that said, this day will come.

What does exist today is a growing ability to manage, and to navigate, what is available in relation to our electronic scholarly editions in a dynamic fashion. This navigation is rooted in humanistic assumptions of the relations that exist within and among texts; it rises out of an accepted understanding of intertextuality. A hypertext, which in its best definition is a "multisequentially read text," 16 embraces such an understanding, and implementations of hypertextual structures rely on the fact that one instance of textual material has association with other instances; in short, such structures rely on the fact that intertextuality exists.

Returning to my example, textual witnesses of Sonnet 138 relate to one another because of their similar textual makeup; while they are unique and individual text instances, we associate them because of their makeup, their content. Much of the material contained in Evans' gloss on Sonnet 138 also relates to that sonnet because of its own makeup - definitions that assist in our understanding of the text of the sonnet, explanations, notes of relations with other texts, and so forth. So, too, with the scholarly discussions that bear on Sonnet 138 as catalogued and presented in Rollins' edition. All these things relate to one another - and, specifically, to the text of Sonnet 138 - because of the nature of their textual content; they have intertextual relations, /pp. 24-25/

16 As per Landow. 
and they participate in a common network of associations that, in this case, centre on Sonnet 138. ${ }^{17}$

Intertextual relations - and, more specifically, the extent of intertextual relations - have historically been very difficult to establish; however, this difficulty is diminishing, especially as textual analysis evolves in areas having to do with the relationship of content within and among texts. These relations are most straightforwardly established in the electronic medium by giving close attention to the resonance of explicit structures within the text, among words and phrases (sometimes, in the field of content analysis, referred to as "semantic patterns"). This attention is word-centred, but not simply so; the ability to track resonating structures relies on the computer's power and potential in determining document content and, more specifically, wordoriented-context. ${ }^{18}$ Success in being able to follow intertextual associations lies in the computer's ability to follow a word or phrase and its associations, within and beyond a single text, by automatically determining and evaluating a context (large and small alike) for that word or phrase.

Though we must here look beyond the parameters that typically define the field of literary studies, a quick /pp. 25-26/

17 I recognise that my argument here is limited to textual data, but also note that developments in electronic data processing (optical character recognition, say, for graphics representing text) and advances in processing textual meta-data that accompanies non-textual data suggest that much non-textual data that one might typically find related to scholarly editions may eventually, though computing processes, be treated textually.

18 The work of Ian Lancashire, and of Don Foster, is exemplary in the way it draws upon the significance of these resonating textual structures. 
glance can reveal much that is beneficial. The realm of computer indexing and language processing teaches us much about our ability to track such structures automatically. ${ }^{19}$ When tracked, these textual structures themselves are capable of operating with machine facilitation in ways akin to hypertextual links. Automatically-generated associations between textual materials can function as do links between textual structures; the structures themselves, in short, act as hypertextual-like nodes (those same bits of text, as noted earlier, that editors might manually demarcate for readers to follow by pointing and clicking). Phrases such as "conceptual-based navigation" are used to describe the act of organising and sorting through large bodies of textual data with this method and ones similar to it.

While our understanding of the mechanics of intertextuality rooted in structures extant in all texts is still evolving, a current understanding of these dynamics urges a growing affinity between linking (based on the principles of, say, editor-determined association) and automated text retrieval (as the computer can associate textual materials that relate to each other). With the assistance of existing software, textual structures themselves are able to act as agents that formalise, in an automated and dynamic manner, the relations between associated textual entities.

\section{Shakespearean Apparatus?}

Given this, we might optimistically consider the act of building a trail of many items through our accumulated knowledge as a process that is largely already completed, but /pp. 26-27/

19 While the progress in this area outpaces scholarly publication mechanisms, at the time of writing one might refer, for example, to work by Allan, Browne, Walker, and Hirata (et al.). 
completed in a way much different than what was envisioned by Bush and a good number of his successors. As it relates to editing, rather than relying on an exemplary editor - an Evans, or a Rollins, or a good many of those who may read this paper - to build that trail and to formalise the relations that exist between materials in standard scholarly editions, we might examine further the implications of recent developments in textual computing; exploring the potential of the humanist's machine, we might consider relying instead upon those who originated the very texts that make up the body of materials related to an edition as defined by the electronic medium's conception of inclusivity. ${ }^{20}$ We might, as editors, consider creating a type of edition in which we set out only the base text, and encourage our readers to use that text, and the explicit textual structures found within, as a guide to related materials that exist beyond the text itself. The "Shakespearean apparatus" I gestured towards in my title thus may, potentially, be nothing at all, and yet it has the potential to be everything in the medium that has relation to a specific instance of Shakespeare's own work.

While this may be an approach some find unfamiliar, and has some potential to be questionable in its /pp. 27-28/

20 My suggestion is intentionally more optimistic than what has been suggested by Landow; in a paper of several years ago, he asks of the hypertextual edition, "What becomes of the concept and practice of scholarly annotation?" and concludes:

Clearly, linking by itself isn't enough, and neither is text retrieval. At first glance, it might seem that one could solve many issues of scholarly annotation in an electronic environment by using sophisticated text retrieval. . . . [But] . . . one cannot automate textual annotation. Text retrieval, however valuable, by itself can't do it all. ("Hypertext Editions") 
implications, such is the groundwork for the scholarly electronic edition that does much to deal with Wissenschaft-era accumulation, and does much to address issues that currently face the new humanist concerned with the management, retrieval, and re-use of scholarly materials. With computer facilitation, this edition operates in a truly dynamic fashion: it annotates itself and assists in making its own apparatus, it automates the process of formalising the associations we take for granted in editions akin to Evans' presentation of Sonnet 138, and it assists in the navigation of scholarship in ways akin to Rollins' variorum presentation of the same sonnet. Moreover, this edition does so in an environment typified by an ever-growing and ever-evolving body of scholarship.

\section{Raymond G. Siemens Department of English Malaspina University-College}

\section{References}

Abbott, Edwin. A Shakespearian Grammar: An Attempt to Illustrate Some of the Differences Between Elizabethan and Modern English. London: Macmillan and Co., 1888.

Allan, James. “Automatic Hypertext Link Typing.” Proceedings of Hypertext '96. New York: ACM, 1996.

The Arden Shakespeare CD-ROM: Texts and Sources for Shakespeare Study. Walton-on-Thames: Arden Shakespeare, 1997.

Bevington, David. Shakespeare. Arlington Heights, IL: AHM Publishers, 1978.

Browne, Glenda. "Automatic Indexing and Abstracting." Library Automated Systems Information Exchange 27 (1996):58-65. Available at: <URL: http://www.zeta.org.au/ aussi/browneg.htm>. 
/pp. 28-29/

Bullough, Geoffrey. Narrative and Dramatic Sources of Shakespeare. 8 vols. New York: Columbia UP, 1957-75.

Bush, Vannevar. "As We May Think." Online. Accessed: September 17, $1997 . \quad$ <URL: http://www.isg.sfu.ca/ duchier/misc/vbush/>. Rptd. from Atlantic Monthly 176 (July, 1945): 101-108.

Delany, Paul, ed. Universities, Languages, and the Global Information Infrastructure. [A special issue of] Text Technology 7.3 (1997).

--, and George P. Landow, eds. Hypertext, Hypermedia and Literary Studies. Cambridge, MA: MIT P, 1991.

--, and George P. Landow, eds. The Digital Word: Text-Based Computing in the Humanities. Cambridge: MIT P, 1993.

Faulhaber, Charles B. "Textual Criticism in the 21st Century." Romance Philology 45 (1991): 123-148.

Finneran, Richard J., ed. The Literary Text in the Digital Age. Ann Arbor: U of Michigan P, 1996.

Fortier, Paul. "Babies, Bathwater and the Study of Literature." Computers and the Humanities 27 (1993-4): 375-85.

Foster, Donald W. "A Romance of Electronic Scholarship; with the True and Lamentable Tragedies of Hamlet, Prince of Denmark. Part 1: The Words." Early Modern Literary Studies 3.3 / Special Issue 2 (January, 1998): 5.1-42 <URL: http://purl.oclc.org/emls/03-3/fostshak.html>.

Fox, Edward A. "Images of Digital Libraries." Keynote Address for NORDINFO Conference: Digital Transfer of Images, Helsinki, Finland (Nov. 10-11, 1994). Available at: <URL: http://fox.cs.vt.edu/NORDINFO.txt $>$. 
/pp. 29-30/

Frye, Northrop. "Literary and Mechanical Models." Keynote address presented at the at the Joint International Conference of the Association for Computers and the Humanities and the Association for Literary \& Linguistic Computing, University of Toronto, Toronto, Ontario (June, 1989). 3-13 in Ian Lancashire, ed. in Research in Humanities Computing 1: Select Papers from the ALLC/ACH Conference. Oxford: Clarendon P, 1991.

Graver, Bruce. "This Is Not a Hypertext: Scholarly Annotation and the Electronic Medium." Profession (1998): 172-8.

Hirata, Kyoji, Yoshinori Hara, Hajime Takano, and Shigehito Kawasaki. "Content-oriented Integration in Hypermedia Systems." Proceedings of Hypertext '96. New York: ACM, 1996.

Keep, Christopher, Tim McLaughlin, and robin. The Electronic Labyrinth. Charlottesville: U of Virginia, 1995. <URL: http://jefferson.village.virginia.edu/elab/elab.html $>$.

Lancashire, Ian. "Phrasal Repetends in Literary Stylistics: Hamlet III.1." In Susan Hockey and Nancy Ide, eds. Research in Humanities Computing 4: Selected Papers from the 1992 ACH/ALLC Conference. Oxford: Oxford UP, 1996.

-. "Computer Tools for Cognitive Stylistics." 28-47 in Ephraim Nissan, and Klaus M. Schmidt, eds. From Information to Knowledge: Conceptual and Content Analysis by Computer. Society of Conceptual and Content Analysis by Computer, SCCAC. Oxford: Intellect, 1995.

-. "Uttering and Editing: Computational Text Analysis and Cognitive Studies in Authorship." Texte: Revue de Critique et de Theorie Litteraire 13/14 (1993): 173-218. 
/pp. 30-31/

-. "Chaucer's Repetends from The General Prologue of The Canterbury Tales." 315-65 in The Centre and its Compass: Studies in Medieval Literature in Honor of Professor John Leyerle. Kalamazoo, MI: Western Michigan U, 1993.

-. "Computer-assisted Critical Analysis: A Case Study of Margaret Atwood's The Handmaid's Tale." 293-318 in George Landow and Paul Delany, eds. The Digital Word. Cambridge, MA: MIT P, 1993.

-. "Chaucer's Phrasal Repetends and The Manciple's Prologue and Tale." 99-122 in Computer-Based Chaucer Studies. CCH Working Papers 3. Toronto: CCH, 1993.

Landow, George P. Hypertext: The Convergence of Contemporary Critical Theory and Technology. Baltimore: Johns Hopkins UP, 1992.

-, ed. Hyper / Text / Theory. Baltimore: Johns Hopkins UP, 1994.

-. "Hypertext, Scholarly Annotation, and the Electronic Edition." Presented on the panel "Hypertext Editions: Theory and Practice" at the Joint International Conference of the Association for Computers and the Humanities and the Association for Literary \& Linguistic Computing, Bergen, Norway (June 27, 1997). <URL: http://gonzo.hd.uib.no/allc-ach96/Panels/Finneran/Landow. html>.

-. "Footnotes, Endnotes, and the Experience of Reading Hypertext." <URL: http://www.stg.brown.edu/projects/hypertext/landow/vp/rea ding.html>. In George P. Landow. The Digital Word and Digital Image - The Electronic Text. <URL: http://www.stg.brown.edu/projects/hypertext/landow/vp/ete xt.html>. 
/pp. 31-32/

Lavagnino, John. "Reading, Scholarship, and Hypertext Editions." TEXT: Transactions of the Society for Textual Scholarship 8 (1996): 109-24. Rpt. The Journal of Electronic Publishing $\quad 3.1 \quad$ (1997). <URL: http://www.press.umich.edu:80/jep/03-01/reading.html>.

Marder, Louis. "Thoughts on a 'Definitive' Edition of Shakespeare: Is it Possible?" The Shakespeare Newsletter 32 (Winter, 1982): 27, 29.

McGann, Jerome. "The Rationale of Hypertext." <URL: http://jefferson.village.virginia.edu/public/jjm2f/rationale.ht $\mathrm{ml}>$.

Nelson, Ted. “A New Home for the Mind?" Datamation [PlugIn] $41.1 \quad$ (1995). <URL: http://www.datamation.com/PlugIn/issues/1995-Jan-15/xan adu.html $>$.

Onions, Charles T. A Shakespeare Glossary. Robert D. Eagleson, rev. Oxford: Clarendon P, 1986.

Partridge, Eric. Shakespeare's Bawdy: A Literary and Psychological Essay, and a Comprehensive Glossary. London: Routledge, 1947.

Ross, Charles L. "The Electronic Text and the Death of the Critical Edition." 225-32 in Richard J. Finneran, ed. The Literary Text in the Digital Age. Ann Arbor: U of Michigan P, 1996.

Shakespeare, William. Shake-speares Sonnets. [Renaissance Electronic Texts.] Ian Lancashire and Hardy Cook, eds. Toronto: CHASS, $1998 . \quad<U R L$ : http://library.utoronto.ca/www/utel/ret/shakespeare/1609int i.html>.

--. Shakespeare's Sonnets. Stephen Booth, ed. New Haven and London: Yale UP, 1977. 
-. The Sonnets. [New Cambridge Shakespeare.] G.B. Evans, ed. Cambridge: Cambridge UP, 1996.

-. The Sonnets. 2 vols. [New Variorum Edition.] Hyder E. Rollins, ed. Philadelphia and London: J. B. Lippincott Co., 1944.

Siemens, R.G. "Disparate Structures, Electronic and Otherwise: Conceptions of Textual Organisation in the Electronic Medium, with Reference to Editions of Shakespeare and the Internet." 6.1-29 in Michael Best, ed. The Internet Shakespeare: Opportunities in a New Medium (Early Modern Literary Studies 3.3 / Special Issue Series 2 [1998]). <URL: http://purl.oclc.org/emls/033/siemshak.html .

-. "A Review of the Arden Shakespeare CD-ROM: Texts and Sources for Shakespeare Studies." Early Modern Literary Studies $4.2 \quad$ (1998): 28.1-10. <URL: http://purl.oclc.org/emls/04-2/rev_siem.html>.

—. " “A worlde of wordes': Conceptions of Textual Organisation in the Electronic Medium, or, The Dynamic Text as Hypertext." Presented on the panel "Theories of Meaning and the Electronic Text" at the Joint International Conference of the Association for Computers and the Humanities and the Association for Literary \& Linguistic Computing, Queen's University, Kingston (June 6, 1997).

-. "The art of mightie words': The Discursive Network of Justice in Edmund Spenser's The Faerie Queene, Book V." Presented at the annual Consortium for Computers in the Humanities conference at the 1994 Learned Societies Conferences, University of Calgary (June 5, 1994). 
/pp. 33-34/

-, and William Winder, eds. Scholarly Discourse and Computing Technology: Perspectives on Pedagogy, Research, and Dissemination in the Humanities. [A special issue of] Text Technology 6.3 (1996) and Computing in the Humanities Working Papers (April 1997) <URL: http://www.epas.utoronto.ca:8080/epc/chwp/>.

Walker, Dwight. "Web Indexing: An Exercise in Hypertext Navigation." Library Automated Systems Information Exchange 27 (1996):50-58. Available at <URL: http://www.zeta.org.au/ aussi/walkerd.html> .

Winder, William. "Texpert Systems." 159-66 in Siemens and Winder and CURL: http://www.epas.utoronto.ca:8080/epc/chwp/winder2/>.

/p. 34/ 